\title{
特集 資源サイクル—2
}

\section{リサイクルを考慮した 製品設計}

ア エコマテリアル，エコデザイン， ECP，LCA 持続可能製品開発

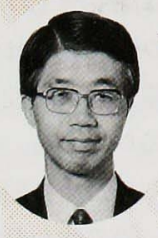

山本 良一

\section{1. 物質文明の矛盾}

従来の製品開発や技術開発では，サステイナビリティー の視点が全く欠落しており，枯渴性資源を大量消費し，大 量の製品を市場に送り込んできた。ある製品を 1 億個，2 億個，10 億個，百年，千年，1万年作り続けたら，どのよ うな環境負荷を与えるかを考虑することは全くなかった。

例えば，電卓に使われている金の使用量を考えてみる と，1台あたりわずか 0.01 グラム， 15 円程度である。し たがって 1 台の電卓をリサイクルするメリットは全くな く，使い捨てられている。ところが日本だけで年間約 1 億 台も生産されている。現在の大量消費の巨大な物質文明で は掛け算するファクタが大きく, トータルで 1 トンの金が 完全に失われている。金は極めて貴重な資源であり，平成 元年に閉山した佐渡の金山も約 400 年の操業で全生産量が 78 トン, 年平均 0.2 トンしか生産していなかった。しか し今われわれは, 電卓で確実に年 1 トンの金を捨てている のである。

これはほかの希少金属についても同じことがいえる。

鉄は現在, 年間 4,600 万トンのスクラップが出ている が, リサイクルする際に現状の技術で除去困難な元素があ り，現実にはバージンの鉄を加え，不純物を薄めて使用し ているのが実情である。全世界で毎年生産されている約 7 億トンにものほる鉄を 1 回リサイクルするのに, 400 億リ ットルの石油に相当する熱エネルギーが必要である。この ようにリサイクルには，膨大なエネルギーが必要である。

非鉄金属の場合, 日本ではアルミニウム $36 \%$, 銅 $47 \%$, 悪鉛 20\%，鉛 39\% しかリサイクルされておらず，あとは

やまもと・りょういち 1969 年東京大学工学部治金学科卒 業, 1974 年同大工学系研究科大学院博士課程修了。1974 年 Max-Planck 金属研究所客員研究員。1976 年東京大学工学部 金属材料学科助手。1980 年 Julich 原子核研究所客員研究員。 1981 年東京大学工学部金属材料学科助教授, 1988 年同大先端 科学技術研究センター教授, 1992 年同大生産技術研究所教授。 工学博士。
環境に散ってしまっている。

また，自動車には 16 種類，カラーテレビには 14 種類と 多くの元素が使われ，新素材を使いこなしているが，製品 の寿命が短く, 自動車は年間 500 万台が廃車となり, 家電 製品も主要 5 品目で年間 1,500 万台が廃棄されている。

つまり，現代の物質文明では，リサイクルが困難な製品 が大量に生産・流通・消費・廃棄され, 資源や環境の有限 さと真っ向から矛盾しているのである。

\section{2. エコマテリアルの開発}

持続可能な発展のためには，「製品・素材の設計・使用に おけるパラダイムの転換」が求められている。これからの 製品・素材は，そのライフサイクル全体において環境への 負荷が最小で，枯渴性資源のリサイクル性に優れたもので ある必要がある。

私は, ライフサイクルにおいて環境負荷を最小に, 再資 源化率を最大にした材料をエコマテリアルと呼び，その開 発が提案されている。再生可能な材料, 生分解性材料, 長 寿命な材料, 非毒性材料, 枯渴性材料の代替材料, 天然材 料などが挙げられる。

科学技術庁でも「環境と調和した材料技術の開発」とい うテーマで現在プロジェクトが進行中である。

いくつかの具体例を挙げてみよう。

製品製造の際に，廃棄される状況を想定して，成分組成 に容易に分離可能な合金の設計が行われている。純度の高 い金属の利用や添加元素の最少化も考えられ, $\mathrm{Fe}-\mathrm{C}-\mathrm{Si}$ $\mathrm{Mn}$ 合金, $\mathrm{Fe}-\mathrm{Cr}$ 合金 (ステンレス), $\mathrm{Al}-\mathrm{Mg}-\mathrm{Si}$ 合金, $\mathrm{Ti}-\mathrm{Al}-\mathrm{Fe}$ 合金, $\mathrm{Fe}$ 合金, $\mathrm{Al}$ 合金, $\mathrm{Ti}$ 合金などは, 熱力 学的に相互に成分分離が可能で, 現在の経済的なベースて も分離が可能である。

リサイクル可能な複合材料の設計も難しいテーマながら 研究がされている。液晶ポリマで熱可塑性樹脂を強化した 材料は, 高温で一相になり, 成形加工して低温にすると二 相層分離して繊維強化材料に戻るという性質があり，リサ イクル可能な自動車用バンパ材料として研究が進められて 
いる。同じような発想で，鉄のファイバで鉄を強化し，使 い終われば温度を上げて全部溶かしてリサイクルできると いう材料の研究もされている。

環境負荷の高い毒性元素を使わないための代替材料も工 コマテリアルである。水道の蛇口の真ちゅう合金には, 削 りやすくするために鉛が添加されているが，鉛の毒性が問 題になり，鉛の代わりにカルシウムを使うようになってい る。

製造業でも，エコマテリアルを素材として導入する企業 も出てきた。日立製作所は 40 数種類のプラスチックをエ ネルギー消費量, リサイクルのしやすさ，材料物性とコス トの観点から総合評価して 4 種類（A〜D）に分け，エコ マテリアル $(\mathrm{A} ・ \mathrm{~B})$ を積極的に使用するという方針を打 ち出している。C・Dに分類されたものは塩化ビニルなど, 燃やすとダイオキシンや塩化水素など毒性のあるものや， リサイクル性が悪いものなどで，これらの材料は家電製品 には使わないことにした。今後は構造材料, 機能材料の工 コデザイン(環境配慮設計)がきわめて重要な課題となろ う。そのためには材料, 製品の環境負荷を定量的に評価す る必要がある。

\section{3. ライフサイクルアセスメント}

材料や製品の環境負荷を定量的に評価する有効な手法と して LCA (Life Cycle Assessment) が近年注目されてい る。

LCA は，産業活動，製品，サービスによる環境への負 荷を最小限に抑えるために 1980 年代から欧米で試みられ たがその後, 地球環境問題の高まりとともに欧米で盛んに 実施されている。

LCA では，例えばある製品を考えたとき，その原材料 の抽出と加工, 製造, 輸送, 使用, 再使用, リサイクル, 最終廃棄の全生涯（いわゆる“ゆりかごから墓場”まで） をとらえ, その全過程における物質・エネルギーの収支を 算出し (インベントリー分析), 各種の環境負荷を評価 （インパクト分析）することによって，製品の環境的側面 から見た品質改善（環境改善分析）を行う。LCA は基本 的に評価の目標設定, データ収集 (インベントリー分析), 環境影響評価 (インパクト分析)，環境改善分析の四つの 段階から構成されている。

インベントリー分析で問題にされるのは，インプットと して枯渴性資源（化石燃料，鉱物資源など），更新性資源 (森林, 水資源など), 再生資源, アウトプットとして大気 污染物質, 水質污濁物質, 固形廃棄物などである。インべ ントリー分析手法としては, 累積収支法, 積み上げ法, 産 業連関法などが知られている。
環境負荷としては地球温暖化，オゾン層破壊，酸性雨， 富栄養化, 土壤污染, 資源枯渴化, 野生生物種の減少など が取り上げられることが多い。

ここで問題になるのは, 同一カテゴリー内での環境負荷 の重み付けと，異なったカテゴリー間での全体としての製 品の環境負荷へ及ぼす相対比率である。特に後者は問題 で, 例えば温室効果ガスとしての $\mathrm{CO}_{2}$, 酸性雨の原因と なる $\mathrm{SO}_{2}$ の総合的な製品の環境負荷への重み付けについ ては, 統一的な理解は得られていない。

現在の LCA の手法では, 資源枯渴化, 野生生物種への 損傷などに対しても有効な評価が行われていない。インパ クト分析の積極的な試みとしては，スイス内務省環境局 (BUWAL) とチューリッヒ連邦工科大学が共同開発した エコポイント法, オランダのライデン大学環境科学センタ 一 (CML) などで開発された重み付け係数法, スウェー デン環境研究所（IVL）とボルボ社で共同開発した EPS 環境負荷計算システムなどがあり, 素材選択, 製品設計な どへすでに応用されているが，世界的な合意が得られてい ないのが実情である。

カテゴリー別の環境負荷を集計する有効な手法がない と, 環境改善分析を行うことが困難になるため, 現在試行 錯誤が行われている段階である。例えば資源枯渴，毒性除 去，污染防止をすべてコストに還元するか，あるいはリス クに還元する方法などである。エコポイントと呼ばれる環 境負荷単位も使用されている。

LCA は 1969 年にコカ・コーラ社の委託で MRI (Midwest Research Institute, 現フランクリン研究所) が, 飲料容器に関する環境影響評価を行ったのが最初といわれ ている。その後, 欧米を中心に, 包装材料を初めとしたさ まざまな問題について LCA 研究が行われてきた。

3.1 LCA をなぜ実施するのか

1979 年には LCA 研究者の国際的ネットワークとして SETAC (Society of Environmental Toxicology and Chemistry）が設立されている。1990 年に, アメリカ・バーモン トでSETAC とプロクター\&ギャンブル社（P\&G 社）の 主催により LCA シンポジウムが開催され, LCA の定義, 用語の明確化, 手法の改善, 適用方法について討論され, のちに 1993 年 SETACより LCA の Code of Practice （実施規約）としてまとめられている。

ここでLCA を何のために実施するのかをまとめてみる と，以下のようになろう。

（1）事業者の材料, プロセス, 製品・サービスの選択, 設計, 販売のための LCA

このなかには, 同一機能製品間の環境負荷の比較, 環境 負荷削減の観点からの改善点の抽出, 環境目標值・基準値 
の達成度の評価などが含まれる。

(2) 政策決定のための LCA

例えば社会システムからみた製品の評価，電力供給，交 通, 運輸, リサイクル, 廃棄処分などの社会システム自体 の評価, 環境ラベルの認証などがある。

(3) コミュニケーションの手段としての LCA

業者間の取引（調達）および, 消費者の製品・サービス の購入時における環境負荷情報の取得あるいは提供。

ヨーロッパを中心として,すでに広範な問題に対して LCA 研究が行われており，実際の製品開発における有力 なツールとして使用されつつある。

しかしながら現状の LCA には，原理的あるいは実行上 いくつかの未解決の問題点があることも事実である。例え ばインベントリー分析のためのデータの収集, データ構 造，データ項目として何を取り上げるか，デー夕の妥当 性, インパクト分析, 環境改善分析の有効な手法, LCA 研究の透明性, 信頼性保証のための有効な制度作りなどで ある。

LCA は万能の手法ではなく, 産業経済活動に伴う環境 負荷を激減させ，物質文明の持続可能性を向上させるため の一つのツールにすぎないことは改めていうまでもない。

LCA を科学的に発展させていくと同時に, 実践的に LCA 適用事例を増やし, 環境改善のために LCA をほか の手法, リスク分析，コスト分析などとともに使いこなし ていくことが, 今ほど求められている時代はない。

このような観点から ISO/TC 207 (環境管理の国際標準 化）でも，SC 5 で LCA の標準化作業が 1993 年 9 月より 開始されている。SC 5 には五つのワーキンググループが 設置され，一般的原理および実施要領，インベントリー分 析，環境影響分析，環境改善分析の標準化作業が行われて いる。

\section{2 国内の動向}

さて,ここでLCAについての国内動向を見てみよう。

我が国では, 1981 年に化学経済研究所が通商産業省委 託調査「新素材導入に伴う省エネルギー効果の分析につい て」で飲料容器などのエネルギー分析を行っている。1991 年からはプラスチック処理促進協会や日本生活協同組合連 合会が, 容器, 包装材について LCA 研究を開始してい る。1992 年には日本エコライフセンターのなかに, 民間 企業を中心とした日本 LCA 研究会が発足し, シンポジウ ムの開催, ケーススタディなど活発な活動を行っている。

1993 年には科学技術庁科学技術振興調査室によるエコ マテリアルプロジェクト研究（1993～98）がスタートし， その三つの柱の一つとして LCA を取り上げ, MLCA（材 料 LCA), 発電プラントなどの社会システム, 洗濯機など
の LCA 研究を行っている。

このような LCA 研究の国内的な盛り上がりを受けて, 1994 年 10 月 $25 \sim 27$ 日, 金属材料技術研究所（つくば市） で我が国では初めての LCA に関する国際会議が開催され た。約 300 人の参加者, 約 80 の論文が発表され, ポス夕 会場では LCA の数種のソフトウェアのデモも行われ, LCA 研究者の熱気を感じ取ることができた。1996 年 11 月に再度, 日本で第 2 回国際会議が開催されることが決ま っている。

また，産官学の研究者が集まって LCA 日本フォーラム が設立されることが決まっている。

\section{4. 欧米諸国の先進的な取り組み}

環境調和型製品開発のために, 欧米諸国では研究を積極 的に行っている。

ヨーロッパでは LCA プロジェクトやエコデザインプロ ジェクトがあり，エコデザインプロジェクトではすでに 4, 5 回国際ワークショップを開催している。昨年の報告 書の中には,「日本はヨーロッパの 2 年遅れだ。日本でも 最近エコデザインの動きが強まってきたが，その情報はヨ 一ロッパに子会社を持っている日本企業を通じて得たもの だ」などと書かれていて，かなりショッキングである。

しかし, 残念ながら出遅れは事実であるが, LCA やエ コデザインに対する国内企業の積極的取り組みが最近目立 ってきた。

ドイツでは, 5 年前からシュツットガルト大学を中心に 企業が集まり，LCA 的な考え方を製品開発に使おうとい う努力をしている。自動車産業, 家電産業, 事務機器産 業, 建築産業など 40 数社が参画している。

オランダは, 2010 年の環境容量を試算して, “Sustainable Netherland”というアクションプランを出し, これを達成するための技術的，政策的な方策を提言してい る。16 年後に世界の市民 1 人あたり, 炭酸ガスは $1.7 卜$ ン以下に抑えるとあるが, 現在, 日本は年平均 1 人あたり 2.6 トンなので相当減らさなくてはいけないことになる。

アメリカでも 1992 年に OTA から “Green Products by Design”というレポートが出され，ここでも，日本の 環境調和型製品 (ECP; Environmentally Conscious Product）開発の遅れが指摘されている。「日本が, 技術 的ポテンシャルがあるにもかかわらず遅れている理由は, 日本政府のリーダシップが足りないこと，市民の環境意識 が低いこと，エコマーク制度はあるが認証基準があまりに も定性的で製品の環境品質を規定するようなものではない こと」と分析している。

IBM はエコデザインを体系的に追求し，ノースカロラ 
イナにはECP の研究センターまでつくりすでに社内で

3 回ほど国際会議を開いている。

それでは環境に配慮した製品 ECP とはどんなものだろ うか。その条件には次のようなものが考えられる。

・簡単にバラバラになるように設計されている(易分解 性設計)。

・リサイクル率が高い。

・エコマテリアルを使っている。

・エネルギーや自然資源の使用を最小にしている。

・クリーンな製造法によって作られている。

・パフォーマンスがいい。

・パッケージングを最少にしている。

・エネルギー効率が非常にいい。

・最終的に廃棄する際にも捨てやすい。

そして, 製品性能が優れていて，なおかつコストが低け

れば申し分ない。

日本企業でも ECP に関する取り組みは始まっている。

例えば, 代替フロン冷蔵庫，分解性に優れたテレビの製造 などがある。プラスチックに代えてステンレスを使いリサ イクル率を上げる努力や，有害物質による環境負荷を少な くする努力もなされており，水銀電池からニッケル水素電 池への切り替えや，鉛を使わないレンズの開発に取り組ん でいるところもある。コピー機のドラムに使用している非 常に毒性のあるセレン合金を $100 \%$ リサイクルするシステ ムを開発した例もある。

$\mathrm{ECP}$ の開発は, 今後の日本の製造業の将来を占う重要 な開発課題であると考えられる。その根拠の一つには, ECP にエコラベルを与え, 優先的に消費者に使用しても らおうというエコラベルのISO による国際標準化の動き がある。今後は官公庁の調達および大企業, 地方自治体な どもエコラベル付き製品を優先調達するようにしていこう というのが欧米の考え方である(グリーン調達)。

例えば, ブルーエンジェルと呼ばれるドイツのエコラベ ルは, 製品のスペックに相当するほど市民の信頼性が非常 に高く，すでに環境品質を規定するものになっている。し かも対象は，台所用品など身の回りの商品だけでなく，工 業製品にまで広がり始めている。したがって，日本企業が ドイツで製品を買ってもらおうとするためには, ブルーエ ンジェルを取得しなければならず，今後は取得する企業が 増えるものと予想される。

\section{5. 持続可能製品開発の課題}

環境調和型素材製品の設計・製造・普及の戦略を考える 場合，まず環境容量を認識することから始めなければなら
ないだろう。環境容量には, フローとしての環境容量とス トックとしての環境容量がある。琵琶湖はどのくらいの污 水を自然浄化できるか, 東京湾にどのくらいの污水を流し 込めるか。これらはフローとしての環境容量。それに対し て, 金属, 化石燃料, 水資源, 土壤, 農耕地, 牧草地, 森 林がどのくらいあるかは，ストックとしての環境容量であ る。この両方の限界を十分に議論しないと, 産業経済活動 の限界を設定して議論ができなくなってしまう。この議論 の上に, 持続可能製品開発の考え方を用いて環境産業を興 すことができる。

環境産業にはフローとしての環境容量を守るキーワード とストックとしての環境容量を守るキーワードの両方があ り,オーバーラップしているものもある。これらの軸を通 じて, 製品アセスメント, グリーンデザイン, LCA のよ うな手法を用いて環境調和型の製品開発を行い, それに厳 しい認証基準でエコラベルを付けてグリーンコンシュマに 買ってもらう。

もう一つ大きな問題は，ECPを作るだけでなく，それ をいかに持続可能消費するかを考えなければ輪が閉じな い。したがって, 環境容量の研究, 環境調和型製品開発, 持続可能消費が三位一体にならなければ，持続可能性を技 術に組み込んでいくことは難しい。

なお，持続可能製品開発の技術課題はさまざまな分野の 専門家による議論によって明確になるものであるが, 大別 して, (1)環境負荷評価法の開発, (2)環境負荷軽減のための 製品設計技術の開発, (3)代替化技術の開発, (4)エコマテリ アルの開発，(5)環境浄化および自然エネルギー利用がある だろうと考えている。

特に，エコプロダクトの開発で現在盛んにいわれている のは，「なるべく物質を使わずに，消費者の最終目的は製 品の所有にあるのではなく製品の機能の利用にある」とい う観点から単位サービスあたりの製品に使用する物質イン パクト量（MIPS=Material Impacts per Units of Service） を最少にしていこうという発想である。リサイクル可能で ない材料は使わず，特に枯渴性資源は完全にリサイクルす ることを目標に，再生資源を積極的に使いこなすような技 術開発をしょうという発想である。

しかし，実体化するには，今後一層の努力が必要であ り，「持続可能な発展」が絵に描いた餅にならないように， 現実の研究開発, 技術開発, 生産活動, あるいはわれわれ のライフスタイルに環境調和の発想をビルトインしていか なければならない。そいう時代にわれわれは生きていると いうことを認識しなければならないと考える。

(平成 7 年 7 月 20 日受付) 